\title{
KONKORDATO HUKUKUNDA KONKORDATO KOMISERİ VE ALACAKLILAR KURULUNUN GÖREVLERİ VE BAĞIMSIZLIKLARI
}

\author{
Yusuf Cahit ÇUKACI \\ Prof. Dr. İnönü Üniversitesi İktisadi ve İdari Bilimler Fakültesi İşletme Bölümü, \\ yusuf.cukaci@inonu.edu.tr

\section{Zeliha KOCA} \\ Öğr. Gör. Malatya Turgut Özal Üniversitesi Arapgir MYO, Muhasebe ve Vergi Bölümü, \\ zeliha.koca@ozal.edu.tr
}




\title{
KONKORDATO HUKUKUNDA KONKORDATO KOMISERI VE ALACAKLILAR KURULUNUN GÖREVLERI VE BAĞIMSIZLIKLARI
}

\section{ÖZ}

Dünya genelinde yaşanan ekonomik krizler ve ülkemizde özellikle 2018 yılında yaşanan döviz kurları ve faiz oranlarındaki iniş̧çıkışlar ekonomide dalgalanmalara yol açmıştır. Döviz borcu olan işletmeler, döviz kurlarında yaşanan artışlar nedeniyle, vadesi gelen borçlarını zamanında ödeyememe durumuyla karşı karşıya kalmışlardır. Ayrıca işletmelerin mali durumları, sıcak paraya duydukları ihtiyaç nedeniyle oldukça olumsuz etkilenmiştir. Özellikle yabancı piyasalar ile çalışan şirketler dövizdeki dalgalanmadan çok fazla etkilenmişlerdir. Yaşanan bu ekonomik sorunlar neticesinde, şirketlerin ve bireylerin iflas etmemeleri, borçlarını daha rahat ödemeleri ve yeniden ekonomiye kazandırılmaları için konkordato uygulamasının önemi artmıştır.

Türk hukuk sisteminde daha önceden var olan konkordatonun yürürlükten kaldırılarak yerine iflas erteleme uygulamasının getirilmesi de istenen sonuçları vermeyince yapılan yeni düzenlemelerle birlikte konkordato uygulaması yeniden Türk Hukuk sistemi içerisindeki yerini almıştır. Yeni konkordato düzenlemesinde yapılan değişiklik ile konkordato komiseri (Komiserler Kurulu)'nin yetkileri farklılaştırılıış ve alacaklılar kurulu getirilmiştir.

Konkordato komiseri, borçlunun faaliyetlerinin sürdürebilmesi, işlerinin devam ettirilebilmesi ve borçlarının yapılan anlaşmaya göre ödenebilmesi amacıyla borçlunun ticari faaliyetlerini denetler ve alacaklıları da gelişmeler konusunda bilgilendirir. Ayrıca işletme tarafından hazırlanan konkordato projesinin başarılı olup olmayacağını da denetler. Alacaklıların menfaatini de koruyan komiser, ifade edilen vazifeleri ifa ederken bağımsızlık içinde hareket etmelidir. Konkordato komiseri ve alacaklılar kurulunu bağımsızlık tehditlerinden koruyacak önlemlerin alınması konkordatodan beklenen faydanın sağlanması anlamında oldukça önemlidir. Alacaklılar kurulunun artan önemi göz önünde bulundurularak hazırlanan çalışmada alacaklılar kurulu ve komiserin bağımsızlık ve tarafsızlığının sürece etkisi ve önemi değerlendirilmektedir. Bu çalışmada konkordato hukukunda yapılan değişiklikler genel olarak değerlendirildikten sonra konkordato komiseri (Komiserler Kurulu) ve alacaklılar kurulu ile ilgili olarak gündeme getirilen yapısal değiş̧iklikler ve özellikle bağımsızlıkları üzerinde durulmaktadır.

Anahtar Kelimeler: Konkordato Komiseri, Alacaklılar Kurulu, Bağımsızlık

\section{DUTIES AND INDEPENDENCE OF TRUSTEE IN COMPOSITION AND BOARD OF CREDITORS IN COMPOSITION LAW}

\begin{abstract}
Due to the world-wide crises and inconstancy in the exchange rates and interest rates occurred in our country, especially the 2018 case, caused economical fluctuations. Businesses done with foreign currency have faced insolvency risk due to the increase in foreign exchange rates. In addition, the financial situation of businesses has been negatively affected due to their need for hot money flow. Especially, companies working in markets which run with foreign currencies were affected by the fluctuation in exchange rates. As a result of these economic imbalance, the concordat (composition) application was brought to the agenda again, so that companies and individuals do not go bankrupt, pay their debts in ease and regain their economy back.

The implementation of bankruptcy postponement by repealing the concordat that exists in the Turkish legal system has not produced the desired results. With the new legal arrangements, the concordat application has taken its place in the Turkish legal system again. The most important of the changes in the new concordat arrangement is the creation of a differentiated trustee in composition (Council of Stewards) and a committee of creditors.

The trustee in composition supervises the commercial activities so that the debtor can continue his/her activities, continue business and pay the debt in accordance with the agreement. The trustee in composition also performs other tasks such as updating creditors and audit success of the concordat project. The trustee in composition, who also protects the interests of the creditors, must maintain his/her independence while performing the duties stated.. Taking measures to protect the trustee in composition and the creditors committee from threats to their independence is very important, in terms of providing the benefit expected from the concordat. In this study, which is prepared by taking into consideration the increasing importance of creditors institution, the influence and importance of board of creditors and trustee in composition are evaluated by means of independence and impartiality. Changes made in concordat law are evaluated generally. Then, the structural changes and especially the independence term were discussed with regard to the trustee in composition and board of creditors.
\end{abstract}

Keywords: Trustee in composition, Board of creditors, Independence 


\section{GİRIŞ}

“İflasın ertelenmesi kurumu” 15 Mart 2018 tarih ve 30361 sayılı Resmî Gazete’ de yayımlanan "7101 sayılı İcra ve İflas Kanunu (İ̈K) ve Bazı Kanunlarda Değişiklik Yapılması Hakkında Kanun" ile yürürlükten kaldırılmıştır. Bu yasanın kaldırılmasıyla 1929 yılından bu yana var olan ancak 2000'li yıllarda şartları borçlulara ağır geldiği için pek fazla tercih edilmeyen konkordato, yapılan yeni düzenlemelerle tekrar gündeme gelmiştir.

28.02.2018 tarih ve 7101 sayılı Kanun'la 2004 sayılı İ̈K'nun konkordatoya ilişkin 285 ve diğer maddelerinde değişiklik yapılarak konkordatonun işlevselliği artırılmıştır. Bu kanun değişikliğinin uygulanmasına ilişkin 2.6.2018 tarih ve 30439 sayılı Resmî Gazete 'de "Konkordato Komiserinin Niteliklerine ve Alacaklılar Kurulunun Zorunlu Olarak Oluşturulmasına Dair Yönetmelik" yayımlanmış ve bu yönetmelik daha sonra uygulamada ortaya çıkan eksiklikler de dikkate alınarak yeniden düzenlenmiştir. $\mathrm{Bu}$ bağlamda yapılan konkordato hukuku içerisinde, borçlu ve alacaklılar arasında karşılıklı olarak menfaatlerin dengesizliğe uğramadan tesis edilebilmesi için farklı konkordato türleri oluşturulmuştur.

"Konkordato; kaba hatlarıyla vade konkordatosu ve tenzilat konkordatosu olarak ikiye ayrılmakta ancak her ikisinin birlikte kullanılabileceği karma bir yöntem olarak da karşımıza çıkmaktadır. Bu ayrım İ̈K'nda yer almamakla birlikte öğretide genellikle kabul edilen bir ayrımdır. Tenzilat konkordatosun da alacaklılar, borçluya karşı, alacaklarının belirli bir yüzdesinin tahsil etmekten vazgeçerler ve borçlu borçlarının konkordatodan kabul edilen kısmını (yüzdesini) ödemek suretiyle borçlarının tamamından kurtulur. Vade konkordatosunda ise borçlu borcunun tamamını ödemek için alacaklılardan bir vade ister veya borçlarını taksitlendirir. Ülkemiz uygulamasında çok kere borçlu, alacaklılarından hem vade hem de tenzilat istemekte ve böylece karma konkordato teklif etmektedir (Hükümet Görüşü s.6). Aslında konkordato felsefe olarak bir uzlaşı olarak kabul edildiğinden mahkeme süreci başlatılmadan konkordato sürecinin oluşması da mümkün olabileceğinden konkordatoyu; adli olmayan konkordato ve adli konkordato şeklinde öncelikle iki ayrıma tabi tutabilmek de mümkündür. Adli konkordato da kapsam bakımından kendi içerisinde; vade konkordatosu, indirim konkordatosu ve karma konkordato olarak kendi içerisinde ayrışabilmektedir" (Çukacı, 2019:8).

Sermaye şirketleri, şahıs şirketleri ve gerçek kişiler için uygulanan konkordato; finansal yapısı bozulan işletmeleri koruyarak tekrar ekonomiye kazandırmayı, borcunu ödeyemeyen borçluyu iflastan kurtarmayı ve alacaklıların, alacaklarının en azından projede belirlenen kısmını alabilmelerini sağlamayı amaçlamaktadır.

$\mathrm{Bu}$ ve benzeri amaçlara ulaşılabilmesi için, yapılan düzenlemelerle oluşturulan yönetmelik gereğince konkordato komiserinin yetkileri artırılmış ve alacaklılar oluşturulan sürece dâhil edilmiştir. Şirketin ve alacaklıların menfaatlerinin korunmasında alacaklılar kurulu ile konkordato komiserine önemli görevler düşmektedir.

$\mathrm{Bu}$ çalışma ile konkordato hukukunda yapılan değişiklikler genel olarak değerlendirilmiş ve konkordato komiseri (Komiserler Kurulu) ve alacaklılar kurulu ile ilgili olarak gündeme getirilen yapısal değişiklikler incelenmiş̧tir. Ayrıca konkordato komiserinin ve alacaklılar kurulunun bağımsızlıkları üzerinde durulacaktır.

\section{KONKORDATO VE TÜRLERİ}

Konkordato; elinde olmayan sebeplerle mali durumu bozulmuş olan ve borçlarını ödeyip (özellikle tacirler açısından) ticari faaliyetlerini devam ettirmek isteyen dürüst borçluların korunması ve bu borçluların alacaklıları arasında eşitliğin sağlanması amacıyla kabul edilmiş bir icra ve iflas hukuku kurumudur (Eroğlu, 2018:21). Bu kurumun amacı, borçluların alacaklılarıyla anlaşma yoluna gitmesi

ve mahkeme denetiminde İIK' da belirlenmiş kurallar çerçevesinde alacaklıların kabul edeceği şekilde borçların yeniden yapılandırılmasıdır. Bu kurum aracılığıyla iyi niyetli ve dürüst borçluların, olabilecek iflaslarının önüne geçilmesi veya borçlarının vadesinin uzatılması ya da borçlarından indirim yapılması gibi uygulamalarla korunması sağlanabilecektir. 
Konkordato müessesi İcra İflas Kanunu'nda madde 285 vd. hükümlerine göre "Adi Konkordato", m. 309 vd. hükümlerine göre "İflastan Sonra Konkordato" ve "Malvarlığının Terki Suretiyle" olarak üç başlık altında düzenlenmiştir.

İKK madde 285 'e göre, Adi Konkordato, borçlarını vadesi geldiği halde ödeyemeyen veya vadesinde ödeyememe tehlikesi altında bulunan herhangi bir borçlunun, vade verilmek veya tenzilat yapmak suretiyle borçlarını ödeyebilmesi veya muhtemel bir iflastan kurtulabilmesi için başvurduğu resmi müessese olarak tanımlanmaktadır.

İflastan Sonra Konkordato, 2004 Sayılı Kanun'un 309 uncu maddesinde "iflâsına hükmedilmiş olan bir borçlu konkordato talep ederse veya bu borçlunun alacaklılarından biri konkordato işlemlerinin başlatılmasını isterse, iflâs idaresi, görüşüyle beraber ikinci alacaklılar toplanmasında veya daha sonra müzakere edilmek üzere alacaklılara bu talebi bildirir" olarak ifade edilmiştir.

Diğer bir yöntem, borçlunun mallarının tamamının veya bir kısmının üçüncü kişiye devredilmesidir. Üçüncü kişi de belirli vadeye yayllan taksitler halinde alacaklılara ödeme yapar (Akil, 2012: 821-822).

\section{KONKORDATO HUKUKUNDA TESISS EDILEN KURUMLAR 3.1. Konkordato Komiseri}

Konkordato komiseri, hazırlanan konkordato projesinin eksiksiz ve hatasız işlemesi adına, kanunda belirtilmiş görevleri yerine getiren kamu görevlisi olarak tanımlanabilir (Altay ve Eskiocak, 2018, 142).

\subsubsection{Konkordato Komiseri ve Atanmast}

Borçlu-alacakl1-mahkeme üçgeninde yönlendirme görevi üstlenen konkordato komiseri çok büyük öneme sahiptir. Konkordato komiseri konkordato kurumunun başarısında ana faktörlerden biridir. Konkordato komiserinin atanma sürecinde de yenilikler yapılmıştır. 30 Ocak 2019 tarihinde yayınlanan "Konkordato Komiserliği ve Alacaklılar Kuruluna Dair Yönetmelik" gereği konkordato komiserinin görevlendirilmesi aşağıdaki şekilde yapılmalıdır:

Mahkeme; komiseri, bağlı bulunduğu bölge adliye mahkemesinde kurulu bulunan bölge kurulu tarafından oluşturulan listeden seçer. Bu listede görevlendirilecek komiser bulunmaması hâlinde liste dışından görevlendirme yapılır ve yapılan bu görevlendirme bölge kuruluna bildirilir.

$\checkmark$ Üç komiser görevlendirilmesi durumunda; komiserlerden biri, mahkemenin bulunduğu ilde faaliyet göstermek şartıyla bağımsız denetçiler arasından seçilir. Seçilecek komiserlerden bir diğerinin ise hukukçu olması tercih edilir.

$\checkmark$ Listeye kayıtlı komiser kendisine verilen görevi kabulle yükümlüdür. Ancak bir komiserlik görevi olanlar mazeret bildirmek koşuluyla görevden çekilebilir.

$\checkmark$ Bir kişi eş zamanlı olarak beşten fazla dosyada geçici komiser ve komiser olarak görev yapamaz.

$\checkmark$ Komiserin görevinin sona ermesi hâlinde bu durum mahkemesince sebepleriyle birlikte derhâl bağlı bulunduğu bölge adliye mahkemesinde kurulu bulunan bölge kuruluna bildirilir (İ̈K. Madde 290).

Konkordato komiserinin nitelikleri ayrıca çıkarılan "Konkordato Komiserliği ve Alacaklılar Kuruluna Dair Yönetmelik" de; komiserde aşağıdaki nitelikler aranır:

a) Türk vatandaşı olmak.

b) Tam ehliyetli olmak.

c) En az dört yıllık lisans eğitimi veren fakültelerden veya bunlara denkliği Yükseköğretim Kurulu tarafından kabul edilen yurtiçindeki veya yurtdışındaki öğretim kurumlarından mezun olmak ve beş yıldan az olmamak üzere mesleki tecrübeye sahip bulunmak.

ç) İflas etmemiş olmak.

d) Son üç yıl içinde görevin gerektirdiği özen yükümlülüğüne uymadığından dolayı komiserlik görevine son verilmemiş olmak. 
e) Disiplin yönünden meslekten veya memuriyetten çıkarılmamış olmak, sanat icrasından veya mesleki faaliyetten yasaklı bulunmamak.

f) Kamu hizmetinden yasaklı olmamak.

g) Fiilen yürütmekte olduğu mesleğinin ilgili mevzuatında, komiserliği yürütmesine engel bir hüküm bulunmamak.

g) 26/9/2004 tarihli ve 5237 sayılı Türk Ceza Kanununun 53 üncü maddesinde belirtilen süreler geçmiş olsa bile; kasten işlenen bir suçtan dolayı bir yıldan fazla süreyle hapis cezasına ya da affa uğramış olsa bile devletin güvenliğine karşı suçlar, Anayasal düzene ve bu düzenin işleyişine karşı suçlar ile zimmet, irtikâp, rüşvet, hırsızlık, dolandırıcılık, sahtecilik, güveni kötüye kullanma, hileli iflas, ihaleye fesat karıştırma, edimin ifasına fesat karıştırma, suçtan kaynaklanan malvarlığı değerlerini aklama veya kaçakçılık, gerçeğe aykırı bilirkişilik veya tercümanlık yapma, yalan tanıklık ve yalan yere yemin suçlarından mahkûm olmamak.

h) Terör örgütleriyle iltisaklı veya irtibatlı olmamak.

1) $\mathrm{Bu}$ Yönetmeliğin 13'üncü maddesi hükmü saklı kalmak kaydıyla komiserlik eğitimini tamamlamış olmak şeklinde sayılmıştır.

Komiserin yasakl1lık sebepleri ve yasak işler "Konkordato Komiserliği ve Alacaklılar Kuruluna Dair Yönetmelik" 6. m.'ye göre; komiser, kendisinin, eşinin, nişanlısının yahut kan ve kayın alt ve üstsoyunun veya üçüncü derece dâhil olmak üzere bu dereceye kadar olan kan ve kayın hısımlarının, kanuni temsilcisi veya vekili, çalışanı, kayyımı ya da yasal danışmanı bulunduğu bir şahsın, menfaati olan işleri göremez ve bu durumda derhâl görevlendirmeyi yapan asliye ticaret mahkemesine haber vermek zorundadır. Mahkeme tarafından müracaat yerinde görülürse komiserin görevine son verilir. Komiser, görevi kapsamında kendisi veya başkaları hesabına sözleşme yapamaz, yaparsa hükümsüzdür.

Komiserlikten kaçınma ve ayrılma sebepleri ise "Konkordato Komiserliği ve Alacaklılar Kuruluna Dair Yönetmelik" 7. m.'ye göre; bedensel engelleri veya sürekli hastalıkları sebebiyle bu görevi yapmakta güçlük çekecek olanlar, uhdesinde birden fazla komiserlik görevi bulunanlar, mahkemece kabul edilecek başka mazereti bulunanlar, komiserlik görevini kabul etmekten kaçınabilirler. Görevi kabulden kaçınma talebi, görevlendirmenin öğrenildiği tarihten itibaren beş gün içinde, görevlendirmeyi yapan mahkemeye verilecek dilekçeyle edilir. Dilekçeye, kaçınma sebebinin yazılması ve varsa belgelerin eklenmesi gerekir. Mahkeme dosya üzerinden yapacağı inceleme sonucunda, talebin yerinde olmadığına karar verirse, komiser görevi kabulle yükümlüdür. Bu karara rağmen komiser görevden kaçınmaya devam ederse mahkeme, başka bir komiser görevlendirir ve kaçınan komiseri de bağlı bulunduğu bölge adliye mahkemesinde kurulu bulunan bölge kuruluna bildirir. Komiser haklı bir mazeretinin ortaya çıkması hâlinde, mazeretin ortaya çıktığı tarihten itibaren beş gün içinde görevden ayrılmayı talep edebilir. İkinci fıkra hükümleri kıyasen burada da uygulanır.

\subsubsection{Konkordato Komiserinin Görevleri}

İ̈K madde 286'daki belgelerin eksiksiz hazırlanması ve borçlunun konkordato talebine istinaden hazırladığı başvuru dilekçesi üzerine mahkeme derhal geçici mühlet kararı verir (Uyar, 2018:24). Geçici mühlet kararıyla birlikte geçici komiser atanır. Geçici komiserin görevleri şu şekilde sıralanabilir;

$\checkmark$ "Borçlunun mevcut malvarlığı durumunun" tespit edilmesi,

$\checkmark$ "Borçlunun hukuki işlemlerini" denetlemesi” (İ̈K. Madde 287/III atfiyla İIKK. Madde 290/II),

Konkordatonun başarılı olma ihtimalini inceleyerek bu konuda rapor düzenlemesi (İIKK. Madde 287/III),

$\checkmark$ "Kesin mühlet" hakkında karar verecek olan ticaret mahkemesine duruşmadan önce yazılı raporunu sunması (IIIK. Madde 289/II),

$\checkmark$ Geçici mühlet süresince borçlunun tasarruf ehliyeti bazı iş ve işlemler için konkordato komiseri onayıyla mümkün olacaktır. Konkordatonun başarılı olmasının mümkün olabileceğine karar verilmesi durumunda borçluya bir yıllık kesin mühlet verilir. Borçlu hakkında kesin mühlet kararı veren 
mahkeme, kararla birlikte yeni bir görevlendirme yapılmasını gerektiren bir durum olmadığı takdirde geçici komiser veya komiserlerin görevlerinin devam etmesine karar verir (İIK. Madde 289/III),

Konkordato komiserinin kesin mühlet süreci içerisinde görevleri (İ̈K. Madde 290):

a) Görevini kanun, Yönetmelik ve dürüstlük kuralları çerçevesinde tarafsız, objektif ve özenle yerine getirilmesi,

b) Kendisine tevdi olunan görevleri bizzat yerine getirilmesi,

c) Görevi sebebiyle öğrendiği sırların gizliliğini sağlaması ve koruması,

ç) Görevi sırasında elde ettiği bilgileri kendisi, yakınları veya üçüncü kişiler yararına doğrudan veya dolaylı bir menfaat elde etmek amaciyla kullanmaması,

d) Görev, unvan ve yetkilerini kullanarak kendisi, yakınları veya üçüncü kişiler lehine menfaat sağlamaması, hediye kabul etmemesi ve arac1lıkta bulunmaması,

e) Görev almak için reklam sayılabilecek nitelikte girişim ve eylemlerde bulunmamasıdır.

Komiserin yukarıda sayılan tüm bu görevleri, konkordatonun tasdiki yargılamasının ön hazırlıklarıdır. Mahkeme komisere bu görevlerin dışında başka görevlerde verebilir (IİK. Madde 290). Buna göre komiser örneğin konkordato projesinin hazırlanmasıyla ve bu kapsamda alacaklar, hissedarlar, yeni finansörler ve işçilere müzakereler yapmakla görevlendirilebileceği gibi, derdest davalarda borçluyu temsil etmekte de görevlendirilebilir. Bu çerçevede örneğin, borçlunun ticari faaliyetlerini bizzat komiser sürdürebilir veya komiser, borçluyu temsil edebilir. Komiserin görevleri mühletin kaldırılmasıyla ve konkordatonun tasdik kararıyla sona erer (Çukacı, 2019:128).

\subsection{Alacaklılar Kurulu}

İ̈K'nda borçlu-alacaklı menfaatini dengeleyecek düzenlemeler yapılmıştır. Bu bağlamda adi konkordato ve iflas erteleme sürecinde daha önce yer almayan Alacaklılar kurulu, 7101 Sayılı Kanunla özellikle 289 vd. maddelerde ve "Konkordato Komiserliği ve Alacaklılar Kuruluna Dair Yönetmelik" m.21-24 ile düzenlenmiştir.

Alacaklılar kuruluna dair 7101 Sayılı Kanunla getirilmiş yeni düzenlemeler, adi konkordato ile ilgili olup söz konusu değişikliklerle (İ̈K. Madde 289/IV) ve ardından çıkarılmış bulunan Yönetmelikle, alacaklılar kurulu adi konkordato bakımından düzenlenmiştir. Malvarlığının terki suretiyle konkordatoda ise, daha önce 4949 Sayılı Kanun'la zaten alacaklılar kuruluna dair düzenleme getirilmiştir. 7101 sayılı Kanunla adi konkordatoda da konu düzenlenince, alacaklılar kurulu her iki tür konkordatoda da yasal zemine sahip hale gelmiştir (Özkan, 2019:53).

Yeniden yapılandırma süreci olarak ifade edebileceğimiz konkordatoda iyi niyetli borçlunun yanında alacaklılarında sürece sorgulayan konumda daha aktif dâhil edilmelerinin sistemin işlerliğini sürekli kılmada ve kurumun kötüye kullanımının engellenmesinde önemli bir etken olacaktır.

\subsubsection{Alacaklılar Kurulunun Oluşturulması}

Alacaklılar kurulu mal varlığının terki suretiyle konkordatoda alacaklılar toplanmasında, adi konkordatoda mahkeme tarafından, oluşturulur.

Alacaklıların menfaatini korumada önemli bir rol üstlenen alacaklılar kurulu oluşturulurken bazı şartların yerine getirilmesi gerekmektedir. "Konkordato Komiserliği ve Alacaklılar Kuruluna Dair Yönetmelik" 21. maddeye göre;

1. Mahkeme tarafindan kesin mühlet kararıyla birlikte veya en geç 2004 Sayılı Kanunun 299'uncu maddesi gereğince alacaklıların alacaklarını bildirmesi ve Kanunun 300'üncü maddesi gereğince borçlunun alacaklılar hakkındaki beyanı alındıktan sonra, yedi alacaklıyı geçmemek, herhangi bir ücret takdir edilmemek ve tek sayıda olmak kaydıyla komiserin de görüşü alınarak alacaklılar kurulu oluşturulabilir.

2. Bu durumda alacakları, hukuki nitelik itibarıla birbirinden farklı olan alacaklı sınıfları ve varsa rehinli alacaklılar, alacaklılar kurulunda hakkaniyete uygun şekilde temsil edilir. 
"Konkordato Komiserliği ve Alacakl1lar Kuruluna Dair Yönetmelik" 22. maddeye göre; alacaklılar kurulunun zorunlu olarak oluşturulacağı haller aşağıdaki gibi belirtilmiştir:

1. Hukuki nitelikleri büyük ölçüde birbirine benzer alacaklar, aynı alacaklı sınıfında yer alır. Rehinli alacaklılar, rehinin kıymetini karşılayan miktardaki alacakları bakımından ayrı bir sınıf olarak kabul edilir.

2. En az üç alacaklı sınıfı bulunması kaydıyla, alacaklı sayısının iki yüz elliyi veya alacak miktarının yüz yirmi beş milyon Türk lirasını aşması hâlinde alacaklılar kurulunun oluşturulması zorunludur.

\subsubsection{Alacaklılar Kurulunun Görevleri}

Konkordato Komiserliği ve Alacaklılar Kuruluna Dair Yönetmeliğinin 23. maddesine göre alacaklılar kurulunun görevleri aşağıdaki gibi belirtilmiştir:

1. Alacaklilar kurulu, komiserin faaliyetlerine nezaret eder, komisere tavsiyelerde bulunabilir ve Kanunun öngördüğü hâllerde mahkemeye görüş bildirir.

2. Alacakl1lar kurulu komiserin faaliyetlerini yeterli bulmazsa, mahkemeden komiserin değiştirilmesini gerekçeli bir raporla isteyebilir. Mahkeme bu talep hakkında borçluyu ve komiseri dinledikten sonra kesin olarak karar verir.

\subsubsection{Alacaklılar Kurulunun Çalışma Usul ve Esasları}

Konkordato Komiserliği ve Alacaklılar Kuruluna dair yönetmeliğinin 24.maddesine göre alacaklılar kurulunun görevleri aşă̆ldaki gibi belirtilmiştir:

1. Alacaklılar kurulu her ay en az bir kere toplanır. Alacaklılar kurulunun aylık olağan toplantıları komiser tarafindan belirlenerek bildirilen gün ve yerde yapılır.

2. Alacaklılar kurulu ayrıca üyelerinin salt çoğunluğunun talebi üzerine her zaman toplanabilir. $\mathrm{Bu}$ hâlde, yapılacak toplantıların komisere bildirilmesi zorunludur.

3. Alacaklılar kurulu toplantıda hazır bulunanların oy çokluğuyla karar alır. Komiser toplantılarda hazır bulunarak alınan kararları toplantıya katılanların imzasını almak suretiyle tutanağa bağlar.

\section{IFLAS ERTELEMELERDE KAYYIM VE KONKORDATO KOMISERININ KARŞILAŞTIRILMASI}

İflas ertelemelerde kayyım ile konkordato komiseri arasında benzer yönler olduğu gibi ve farklı yönler de bulunmaktadır. Aşağıda farklar ve benzerlikler karşılaştırmalı olarak verilmiştir:

Tablo 1.Ifflas Ertelemelerde Kayyım ve Konkordato Komiserinin Karşılaştırılması

\begin{tabular}{|c|c|}
\hline Kayyım & Konkordato Komiseri \\
\hline $\begin{array}{l}\text { Ticaret mahkemesi tarafından atanır (Türk Ticaret } \\
\text { Kanunu (TTK) Madde 235). }\end{array}$ & İcra mahkemesi tarafindan atanır (İ̈K. Madde 290). \\
\hline $\begin{array}{l}\text { Adli kamu hizmetlerini yerine getirmektedirler } \\
\text { (Ermenek, 2010:329). }\end{array}$ & $\begin{array}{l}\text { Adli kamu hizmetlerini yerine getirmektedirler } \\
\text { (Ermenek, 2010:329). }\end{array}$ \\
\hline $\begin{array}{l}\text { Görevlerini yerine getirirken alacaklı ve borçlular } \\
\text { arasından eşit mesafede durmak ve kanunun getirdiği } \\
\text { bir ayrıcalık durumu söz konusu olmadıkça, taraf } \\
\text { menfaatlerini gözetirken adil bir şekilde davranmak } \\
\text { zorundadırlar (Çetin, 2011:39). }\end{array}$ & $\begin{array}{l}\text { Görevlerini yerine getirirken alacaklı ve borçlular } \\
\text { arasından eşit mesafede durmak ve kanunun getirdiği } \\
\text { bir ayrıcalık durumu söz konusu olmadıkça, taraf } \\
\text { menfaatlerini gözetirken adil bir şekilde davranmak } \\
\text { zorundadırlar (Çetin, 2011:39). }\end{array}$ \\
\hline $\begin{array}{l}\text { Görev süresince gözetim ve denetim altında tutulur } \\
\text { (Ayvaz,2005:344). }\end{array}$ & $\begin{array}{l}\text { Görev süresince gözetim ve denetim altında tutulur } \\
\text { (İIK. Madde 290). }\end{array}$ \\
\hline $\begin{array}{l}\text { Ticaret mahkemesi tarafindan borçluların malvarlığı } \\
\text { üzerindeki tasarruf yetkisinin kaldırılarak kayyıma } \\
\text { verilmesi mümkündür. }\end{array}$ & $\begin{array}{l}\text { İcra mahkemesi tarafindan borçluların malvarlığ } \\
\text { üzerindeki tasarruf yetkisinin kaldırılarak tamamen } \\
\text { konkordato komiserine verilmesi mümkündür. }\end{array}$ \\
\hline $\begin{array}{l}\text { İ̈K 179/a-3 maddesi gereğince, TCK'nın anonim } \\
\text { şirketlerde yönetim kuruluna verdiği tüm yetkilerin } \\
\text { kullanılmasının, yönetim kurulunda alınacak kararların } \\
\text { ve yapılacak faaliyet ve işlemlerin geçerliliğini onaylar. }\end{array}$ & $\begin{array}{l}\text { Konkordato komiserini atayan icra mahkemesi, atama } \\
\text { kararında borçlunun faaliyetlerinin geçerliliğini } \\
\text { konkordato komiserinin nezaret etmesine veya onayına } \\
\text { bağlı k1labileceği gibi, konkordato komiserinin }\end{array}$ \\
\hline
\end{tabular}




\begin{tabular}{l|l}
\hline $\begin{array}{l}\text { Bu yetki, kayyımlar bakımından çok daha hafif şartların } \\
\text { oluşması ile verilebilir. }\end{array}$ & $\begin{array}{l}\text { borçlunun yerine geçerek işlem ve faaliyetlerde } \\
\text { bulunmasına da karar verebilir (İ̈K. Madde 290/1). Bu } \\
\text { yetki çok daha olağanüstü şartların bulunmasını } \\
\text { gerektirecektir (Ermenek, 2010:331). }\end{array}$ \\
\hline $\begin{array}{l}\text { Kayyımlar bakımından kanunda kayyım olarak } \\
\text { atanabilecek kişiler ve kayyımın sorumluluğu } \\
\text { konularında açık bir düzenleme yapılmamıştır. Bu kuycunun konkordato komiserinin görev ve } \\
\text { nedenle kayyıma somut olayın gereklerine göre hareket } \\
\text { edebilmesi ççin çok daha fazla takdir yetkisi tanımıştır. }\end{array}$ & $\begin{array}{l}\text { kullanarak yaptığı işlemlere karşı gidilebilecek yasal } \\
\text { yollar, konkordato komiseri olarak atanabilecek kişiler } \\
\text { ve konkordato komiserinin sorumluluğu konularında } \\
\text { açı yasal düzenlemeler getirilmiştir (Ermenek, } \\
\text { 2010:333). }\end{array}$ \\
\hline
\end{tabular}

\section{BAĞIMSIZLIK}

Bağımsızlık, kelime olarak bağımsız olma durumunu ifade etmektedir. Bağımsız kelimesi ise; davranışlarını, tutumunu, girişimlerini herhangi bir gücün etkisinde altında kalmadan düzenleyebilen, özgür ve müstakil olmak anlamına gelmektedir (Erken, 2009:18). Uluslararası iç denetim standartlarına göre bağımsızlık ise; objektifliği veya objektiflik görüntüsünü bozabilecek şartların dışında olma hali olarak tanımlanmıştır (IIA, 2011:22). Başka bir tanıma göre bağımsızlık "bulunduğu şartlara bakmaksızın, icra ettiği mesleğinin kendisine yüklediği sorumluluklarının bilincinde, vicdani değerleri ve kamuya karşı sorumluluğu her zaman için şahsi menfaatlerinin önünde tutarak çalışmak" demektir (Erdikler,2003:1).

Literatürde bağımsızlık tehditleri olarak belirtilen yani denetçinin bağımsızlığını tehdit eden, risk yaratan başlıca tehdit türleri şunlardır (Uzay, 2004:438-439):

Kişisel menfaat tehdidi: Finansal veya kişisel menfaat çatışması, yasal denetçilerin bağımsızlığını tehdit edebilir. Örneğin, bir müşteri işletmeden sağlanacak doğrudan veya dolaylı finansal menfaat, müşteri işletmede denetim veya denetim dışı ücretlere aşırı bağl1lık, ödenmemiş ücretleri tahsil etmek veya işletmeyi kaybetme korkusu.

Kendi kendini denetleme tehdidi: Kendi kendini inceleme prosedürlerinin yürütülmesinde, objektifliğin korunmasında güçlükle karşılaşılmasıdır. Örneğin, tamamıyla işletme yönetimi tarafından alınması gereken kararları almak veya alınan kararlara katılmak gibi.

Savunma tehdidi: Müşteri işletmenin mahkeme veya başka durumlarında (Örneğin; işletmede menkul kıymetlerin veya ortaklık paylarının değerinin artırılmasıyla ilgili; hukuki ihtilafta müşterinin taraf olarak savunucu olması; müşteri işletmenin denetçiye karşı dava açması gibi), yasal denetçinin savunmada veya tam tersi muhalefette olması, bağımsızlığını tehdit eder.

Samimiyet veya güven tehdidi: Yasal denetçi, müşteri işletmenin kişiliğinden ve niteliklerinden aşırı derecede etkilenip, müşteri işletmenin menfaatlerine aşırı derecede sempati gösterebilir. Örneğin; müşteri işletme personeli ile oldukça uzun süreli ve oldukça yakın ilişkiler, işletmeye aşırı güven duyulmasına veya yeterli objektif testlerin yapılmamasına yol açabilir.

Yıldırma tehdidi: Müşteri işletmenin güçlük çıkarması veya etkili (sözü geçen) bir konumda olması gibi korkulardan oluşan tehdidin, bağımsız denetçiyi objektif olarak faaliyet göstermekten caydırma ihtimali bulunmaktadır.

Bağımsız denetçiler için sayılan yukarıda açılanan tehdit türleri kıyas yoluyla konkordato komiserleri içinde düşünülebilir. Denetçinin bağımsızlığına yönelik hukuk sistemimizdeki önlemlerin konkordato komiseri ve alacaklılar kurulu içinde uygulanabileceği değerlendirilebilir.

\section{Konkordato Komiserinin Bağımsızlı̆̆ı}

Konkordato projesinin tamamlanmasında önemli bir rol üstlenen konkordato komiserleri görevlerini yaparken tüm konularda bağımsız davranmalıdırlar. Konkordato komiserinin, borçlunun faaliyetlerine nezaret ederken, alacaklılara konkordatonun seyri ve borçlunun güncel mali durumu hakkında bilgi verirken ve mahkemenin istediği ara raporları sunarken tarafsız bir bakış açısıyla hareket etmesi, 
bağımsızlığını ifade eder. Konkordato komiseri şirket menfaatleri ile alacaklıların menfaatleri arasındaki olası anlaşmazlıkta tarafsız kalabilmelidir.

Komiser bağımsızlığını koruma açısından çeşitli tehditlerle karşılaşabilir. Konkordato Komiserliği ve Alacaklılar Kuruluna Dair Yönetmeliğinin 5. maddesine göre bir kişi eş zamanlı olarak beşten fazla dosyada geçici komiser ve komiser olarak görev yapamaz. Bu kısıtlamanın getirilmesi yerinde olmuştur. Konkordato komiserinin gelirine belirli kıstaslara göre sinırlama getirilmezse, aynı zaman diliminde birden fazla şirkette komiserlik yapmanın gelir seviyesini arttırmasıyla komiser, gelirin devamlılı̆̆ın sağlayabilmek adına borçlu ile birlikte hareket ederek, üçüncü kişileri aldatma yolunu seçebilir. Gelir seviyesinin üst sınırının olmaması mesleki ahlak zafiyetine neden olabilir. Ya da düşük ücret olması durumunda yasal olmayan yollardan ücret elde etme yolunu seçebilir. Menfaat tehdidi olarak ifade edebileceğimiz bu durumu önleyici düzenlemeler yapmak bu tehdidi asgariye düşürülebilecektir. Denetçi bağımsızlığını sağlamaya yönelik kurallar olmasına rağmen komiserin bağımsızlığını sağlamaya yönelik kurallar hukuk sistemimizde doğrudan yer almamaktadır. Bu kuralların tespit edilip, gerekli düzenlemeler yapılıp, hukuk sistemimizde yer alması şüphesiz mahkemeye komiseri denetleme konularında da yardımci olacaktır.

Konkordato komiserinin bağımsızlığının bozulması konkordato sürecinin bütününe zarar vererek domino etkisi yaratabilir. $\mathrm{Bu}$ nedenle işletmelerin sürdürülebilirliğini sağlamada komiserlik müessesesine düşen sorumlulukların, bağımsızlık ilkeleri doğrultusunda ve tüm paydaşların korunması amac1yla düzenlenmelidir.

\subsection{Alacaklılar Kurulunun Bağımsızlı̆̆ı}

Konkordatodan beklenen yararın sağlanabilmesi için alacaklıların da haklarının korunması, sorumluluklarının belirlenmesi ve borçlular tarafından bu müessesenin kötüye kullanımının önüne geçilmesi gerekmektedir.

“Tenzilat konkordatosunda alacaklılar, borçluya karşı, alacaklarının belirli bir yüzdesini tahsil etmekten vazgeçerler ve borçlu, borçlarının konkordatoda kabul edilen kısmını (yüzdesini) ödemek suretiyle borçlarının tamamından kurtulur. Vade konkordatosunda ise borçlu borcunun tamamını ödemek için alacaklılarından bir vade ister veya borçlarını taksitlendirir" (Çukacı, 2019:8). Bu iki konkordato türünde de alacaklıların, alacaklarının belirli bir yüzdesini tahsil etmekten vazgeçmeleri veya borçlarını taksitlendirmeleri konkordato müessesesi için önem arz etmektedir. Adi konkordato sürecinde mahkemece, malvarlı̆gının terki suretiyle konkordatoda ise, alacaklılar toplanmasında oluşturulan alacaklılar kurulu, alacaklı/lar menfaatlerinin korunmasında önemli bir rol oynar (Özkan, 2019:53). Alacaklılar kurulu üyelerinin bu önemi gereği bütün alacaklıların haklarını aynı oranda savunmaları gerekir. Burada menfaat tehdidine karşı, bağımsızlığı sağlayıcı önlemlerin alınması gerekir. Aksi takdirde sadece temsilcisi oldukları alacaklı grubunun menfaatlerini koruma amaçlı faaliyette bulunmaları söz konusu olabilir.

Borçlunun sunduğu konkordato projesinin alacaklılar arasında oylamaya sunularak, Kanunda öngörülen çoğunluğun sağlanması durumunda kabul edilebilecek olması (ïK. Madde 302), alacaklıları, projenin kabulü hususunda etkin kılmıştır. Bu durum uygulamada kötü niyetli borçlunun projenin kabulündeki oy hakkı sebebiyle fason alacaklı türetmesine neden olabilecektir. Bir başka ifade ile borçlu, kendi lehine bir seçmen yaratabilir. Alacaklılar kurulunun bağımsızlığını zedeleyecek bu ve benzeri durumlara karşı mahkemenin kurul üyesini görevden alıp alamayacağı meselesi Kanunda düzenlenmiş değildir. Bu düzenlemenin yapılması gerekmektedir.

\section{SONUÇ VE ÖNERILER}

İşletmeler insanların istek ve ihtiyaçlarını karşılamak amacıyla mal ve hizmet üretirken, kar sağlamanın yanında işletmenin sürekliliğini sağlamayı da amaç edinirler. İşletmelerin sürekliliklerini sağlayabilmeleri ise borçlarını ve varlıklarını yönetebilme yeteneklerine bağlıdır. İşletme içi ve işletme

dışı faktörler (yetersiz yönetim, döviz kurlarında yaşanan dalgalanmalar, faiz oranlarının yükselmesi vb.) nedeniyle işletmelerin sürekliliklerini sağlamaları zorlaşabilir; hatta doğru önlemler alınmazsa işletmelerin iflası bile söz konusu olabilir. Bir işletmenin faaliyetlerinin kesintiye uğraması veya olası bir iflas, benzer ya da farklı sektörlerdeki işletmeleri de olumsuz yönde etkileyebilir. Bu nedenle kanun 
koyucu, bu olumsuz durumların önüne geçebilmek için, iflas ertelemesi ve konkordato gibi kurumlarla tedbir alma yoluna gitmiştir.

Ülkemizde 2003 yılından itibaren uygulanan iflasın ertelenmesi kurumu, uygulamada ortaya çıkan sorunlar ve kötüye kullanımlar nedeniyle, kendisinden beklenen amaca hizmet edememiştir. Borçlu ve mahkeme arasında işleyen süreçte, alacaklıların söz hakkının olmaması da bu sistemin işlerliğini olumsuz yönde etkileşmiştir. İ̈K'nda değişiklik öngören yasa ile iflasın ertelenmesi kurumu kaldırılmıştır. Yapılan yeni düzenlemeyle borçlunun alacaklılarla anlaşarak, mahkeme denetiminde borç ve alacakların yeniden yapılandırılması söz konusu olmaktadır. Alacaklıların da sürece dahil edildiği yeni düzenlemeyle konkordato kurumu ile taraflar arası anlaşmazlıkların çözümünde daha etkili olacağı düşünülmektedir. Konkordato mühleti içerisinde borçlu hem işlerine devam eder hem de alacaklılarla yaptığı anlaşmanın gereklerini yerine getirmeye çalışır. Bu süreçte borçlu, konkordato komiseriyle birlikte hareket eder. Sürecin verimli bir şekilde yürütülmesi konkordato komiserinin yetkinliği ile ilgilidir. Konkordato komiserinin yetkinliğinin artırılmasıyla birlikte gelirine de belirli kurallara göre sınırlama getirilmelidir. Gelir seviyesinin üst sınırının olmaması ya da gelir seviyesinin düşük olması mesleki ahlak zafiyetine neden olabilir. $\mathrm{Bu}$ durum konkordato komiserinin bağımsızlığına gölge düşürür. Proje kabulünde alacaklıların oy hakkının olması, kötü niyetli borçlu tarafından gerçek olmayan alacaklı türetilmesine neden olabilir. Bu durum alacaklılar kurulunun bağımsızlığını tehdit etmektedir.

Borçlulara borçlarını ödeme ve iflastan kurtulma anlamında ikinci bir şans olarak sunulan konkordatonun başarısı, konkordato komiseri ve alacaklılar kurulunun bağımsızlı̆̆ ile gerçekleşebilir. Mali durumu bozulan işletmelerin yeniden ekonomiye kazandırılmaları amacıyla faaliyet gösteren konkordato müessesesinin zarar görmesi işletmenin yanında işletme ortakları, tedarikçiler, tüketiciler, devlet vb. paydaşları da zincirleme olumsuz etkileyecektir. Bu olumsuz durumları önleyebilmek için, denetçi bağımsızlığını sağlamaya yönelik kurallardaki gibi, komiserin ve alacaklılar kurulunun bağımsızlığına yönelik kuralların da hukuk sistemimizde yer alması gerekmektedir.

\section{KAYNAKLAR}

1. Akil, C. (2012). "Malvarlığının terki suretiyle konkordatoda konkordato tasfiye memuru", Ankara Üniversite Hukuk Fakültesi Dergisi, 61 (3), 819-858.

2. Altay, S. ve Ali E. (2018). 7101 Sayılı Kanun'la Yapılan Düzenlemelerin Işı̆̆ııda Konkordato ve Yeniden Yapılanma Hukuku. İstanbul: Vedat Yayıncılık. 4.Basım.

3. Çetin, Ö.K. (2011). Iflasın Ertelenmesi Bağlamında Kayyımlı, Ankara: Adalet Yayınevi, 1. Baskı.

4. Çukacı, Y.C. (2019). Konkordato, Bursa: Ekin Basım Yayın.

5. Erdikler, Ş. (2003). “Bağımsız Denetimin Sahibi Kim?”, Dünya Dergisi.

6. Erken, H. (2009). "Denetimde Bağımsızlık Kavramı”, Denetişim Dergisi, http://kidder.org.tr/wpcontent/uploads/denetisim/1.\%20SAYI.pdf (01.05.2017).

7. Ermenek, İ. (2010). Iflasın Ertelenmesi, Ankara: Adalet Yayınevi, 2. Bask1.

8. Eroğlu, O. (2018). Uygulamada Konkordato, Ankara: Seçkin Yayıncılık, 21. Bask1.

9. Konkordato Komiserliği ve Alacaklılar Kuruluna Dair Yönetmelik, 30 Ocak 2019 Çarşamba Sayı: 30671.

10. Özkan, Y. (2019). "Konkordatoda Alacaklılar Kurulu”, Hukuk Dergisi 1(2).

11. Ayvaz, T.S. (2005). İcra Iflas Hukukunda Yeniden Yapılandırma, Ankara: Yetkin Yayınc1lı, 1.Bask1.

12. Uyar, T. (2018). Yeni Konkordato Hukukumuzun Temel İlkeleri, Ankara: Türkiye Barolar Birliği Yayınları, 2. Bask1.

13. Uzay, Ş. (2004). "Türkiye de Denetçi Bağımsızlığı", MÖDAV Muhasebe Bilim Dünyası, pp.435485.

14. IIA (2011). Uluslararası İç Denetim Standartları, https://global.theiia.org/translations/PublicDocuments/Standards_2011_Turkish.pdf 25.12.2020). 